\title{
AIR POLLUTION : ITS CAUSES AND CONSEQUENCES WITH REFERENCE TO KATHMANDU METROPOLITAN CITY
}

\author{
Dilli Raj Gautam, PhD \\ Reader \\ Department of Geography Education \\ Tribhuvan University, Kirtipur \\ drgautam16@gmail.com
}

\begin{abstract}
Rapid increase in human and vehicular population along with a continuous increase in primary energy consumption in Kathmandu metropolis results in continuous increase in TSP, PM $\mathrm{SO}_{2}, \mathrm{CO}, \mathrm{NO}_{2}$ and other air polluting dust smog and gases. Emissions from automobiles, factories and domestic heating, cooking, refuse burning in Metropolitan areas have created air pollution which has threatened the well being of the city dwellers. Housing congestion, traffic congestion and various commercial activities have produced high amount pollutant emissions in various forms which have ultimately polluted the surrounding environment and adversely affected human health in the metropolis.
\end{abstract}

Key words: Metropolis, energy, emissions, human health and environment

\section{Introduction}

Air pollution may be defined as the presence of one or more contaminants such as dust, fumes, gas, mist, odor, smoke or vapor in the atmosphere which may prove to be injurious to plant, animals and human life (Perkins, 1974). It can also be defined as the outdoor ambient atmosphere containing harmful pollutants which adversely affect man and his environment. It is the disequilibrium condition of the air caused due to introduction of foreign elements from natural as well as anthropogenic sources to the air so that the air becomes injurious to biological communities in general and human communities in particular (Singh, 1995). To a large extent man himself is responsible for air pollution. His activities, careless technology, casual attitude and lack of awareness may contribute to air pollution. Sometimes natural factors such as fog, mist, bacteria, wind velocity and its direction and volcanic ash may be the cause of air pollution. If the unpolluted gases in the atmosphere are contaminated with man made pollutants i.e: aerosol, dusts and particulate matters, gases and fumes of sulfur compounds $\left(\mathrm{SO}_{2}, \mathrm{H}_{2} \mathrm{~S}\right)$, nitrogen compounds $\left(\mathrm{NO}, \mathrm{NO}_{2}, \mathrm{NH}_{3}\right)$, oxygen compounds $\left(\mathrm{CO}, \mathrm{CO}_{2}\right.$, $\mathrm{O}_{3}$ ), Halogen Compounds $(\mathrm{HF}, \mathrm{HCl})$, organic compounds (aldehydes), Hydrocarbons and radioactive compounds (radioactive gases), the air tend to be polluted (Gautam, 2000). Moreover large increases in population causing loss of forest and advancement of modern technology have resulted in air pollution problem in recent years.

The impact of polluted air on health takes into account the type and duration and amount of contaminants present in the air. The air at the surface consists primarily of nitrogen and oxygen 78 and 21 percent respectively. Much of the remaining one percent is water vapor and carbon dioxide. The activity of humans in generating energy, manufacturing goods and disposing of wastes results in release into atmosphere of a number of pollutants that alter plant metabolism and induced diseases (Tiwari, 2010). Regarding the human health, air pollution can cause severe and chronic health ailments particularly respiratory one. In this connection, air pollution is a growing menace to health in urban areas, especially, in the cities of the valley region. Air pollutants may exist in a particular place for a long time because of climatic factors. Inhalation of such contaminated air adversely affects the respiratory system of the man. Hence, the study of the air pollution especially in the urban areas is essential to overcome the human health problem. In the case 
of air pollution very few geographical studies have been done in Nepal. In this context, present paper is an attempt to identify the causes of the air pollution, evaluate its spatial pattern of air quality, interpret possible consequences of air pollution and recommend mitigating measures for controlling air pollution.

\section{Methods and Materials}

Present paper is based on both primary and second sources of information. In order to collect primary data, air pollution monitoring was made in the months of December, 1998 and April, 1999. Monitoring stations were selected from residential, commercial and industrial areas. TSP and $\mathrm{PM}_{10}$ were collected by the low volume air sampler (Sibata Japan Model AN200 Anderson type with the air flow rate of 28.5litres/minutes). The $\mathrm{SO}_{2}$ and $\mathrm{NO}_{2}$ data were obtained from the samples collected by Enviro Tech, India Model APM820 which was run at air flow rate of 0.3 litres / min for 24 hours. The $\mathrm{CO}$ content in the ambient air was measured at the sampling station by operating $\mathrm{CO}$ gas detector tube and the recorded $\mathrm{CO}$ was tabulated for analysis, Secondary sources of information were collected from different published and unpublished official documents. Descriptive and analytical techniques were applied for data presentation.

\section{Discussion and Interpretation}

\section{Causes of Air Pollution}

In nature the air remains free from industrial, commercial or urban influence which seems to be relatively pure. To such a pure air, various gaseous and particular matters enter by human activities like industries, dumping of solid and liquid waste, smog from domestic cooking, airplanes, railway engines and automobiles. When these emissions are mixed in the air, they pollute the air and adversely affect life of plants, animals and human health and damage valuable and enchanting buildings and monuments. The fossil fuel emissions are one of the major sources of air pollution. The emitted gases include carbon monoxide, sulfur dioxide, and oxides of nitrogen, volatile organic compounds, fly ash and other suspended particulate matters.
Pollutants may be of primary origin emitted directly from the source. Carbon monoxide (CO) and Nitric Oxide (NO) are primary pollutants produced during the combustion of carbon based fuels. Further oxidation of $\mathrm{NO}$ forms $\mathrm{NO}_{2}$ and is known as secondary pollutant. Ozone $\left(\mathrm{O}_{3}\right)$ is another secondary pollutant formed in the atmosphere by the action of sunlight on $\mathrm{NO}_{2}$. In urban areas, $\mathrm{O}_{3}$ forming reactions are enhanced by the presence of hydrocarbons from vehicle exhausts.

\section{Sources of Air pollution and Problems in Kathmandu Metropolis}

Besides Indian metropolitian cities (Kanpur, Mumbai, Chennai, Calcutta, Delhi etc), some other third world cites like Sao Paulo, Santiago, Bangkok, Shanghai and other cities in Southern China have been facing severe air pollution problem (Sing, 1985, Hardog, 1992). Compared to other metropolitan cities, the problem of air pollution in Kathmandu is not so alarming. However, with increasing number of automobiles, the situation is likely to worsen. Similar condition prevails in other cities of Nepal such as Pokhara and Biratnagar (CEDA, 1989). At Kathmandu, Pokhara and Biratnagar the suspended particulate matter (SPM) is high. An attempt has been made to evaluate the increased air pollution level created by unprecedented growth of human population, housing congestion, traffic congestion, increased commercial and various other activities. All these have produced high amount of pollutant emissions in various forms which have ultimately polluted the surrounding environment and adversely affected the human health in the metropolis.

More than hundred brick kilns and factories were established in south and east of the Kathmandu at 5-10 km periphery. The coal used in these industries emits dust, smoke and $\mathrm{CO}$ which have added to the air pollution problem. The poorly maintained vehicles along with the congestion of traffic problem produced large amount of lead emissions. Besides these, emissions from domestic cooking, heating and burning of coal and cow dung also contributes to the air pollution in Kathmandu. Though the urban people have environmental awareness 
since 1980, the increasing population pressure, modernization, and demand of more energy for domestic purpose, public utilities and industries have caused the increase in air pollution day by day. Thus, pollution generated by energy used in large quantities has become a serious problem in the urban environment of Nepal. The large number of vehicles with low efficiency led to the emission of toxic pollutants. The adverse impact of such pollutants has also been tolerated by the urban dwellers so far.

\section{Automobile Pollution in Kathmandu Metropolis}

In the Kathmandu metropolis, the automobile exhaust and vehicular emissions are the major sources of air pollutions. Besides these, building construction and domestic sources also pollute the urban environment. Large increase in number of automobiles has created an alarming air pollution problem.

It is evident from table 1 that the total number of the vehicles registered in Kathmandu valley was 575417 whereas up to the mid of 2000 it was only 186521 . It shows an increase in vehicle by $208.49 \%$ within 10 yrs. In Kathmandu, the motorcycles and scooters share about $76 \%$ of the total number of vehicles followed by car, jeep, vans $16.36 \%$ and heavy vehicles $5.59 \%$ (Table

The major factors causing air pollution in the city are old and poorly maintained vehicles, narrow roads and lanes of the city and high frequency of idling and deceleration lead to generate high emission. Besides these, the vehicular pollution also depends upon the quality and quantity of fuels and efficiency of combustion.

\section{Industrial Pollution}

In the Kathmandu valley, marble industry and brick factories are the polluters of the air. Some existing industries like Chirag Foam Industry, Guheswori Rolling Mills, Nepal Gas Industry, Ratna Feed Industry, Paper and Pulp Industry, Nepal Biscuit Company and others located in Kathmandu are still polluting the environment. In case of Chirag Foam Industry (Balaju) which produces mattress, pillow and cushion through a short synthetic chemical process, the main environmental problem due to the fumes and the gases from the synthetic chemicals like polyol and toluene di-isocynate (TDI) of which later one is considered to be hazardous and produces indoor pollution. The mixing of poliyol and TDI poses health hazard to the workers causing respiratory diseases, eye irritation and nose and throat problems. Though this indoor air pollution has been controlled to some extent by the provision of exhaust fan and ventilation, they are inadequate and affect the surrounding environment. Bottlers Nepal and Swastik Aerate Products (Sinamangal) which produce soft drink also emit carbon monoxide causing air pollution.

\section{Population Increase}

Besides immigrants, who have settled, daily commuters are also major source of air pollution

Table 1. Total Number of Vehicles Registered in Kathmandu till December, 2010.

\begin{tabular}{|l|l|l|l|}
\hline S.No. & Types of vehicles & Number & Percentage shared \\
\hline & Heavy & 6124 & \\
1. & Bus & 8160 & 1.06 \\
2. & Minibus, Microbus & 13651 & 2.37 \\
3. & Truck, Mini trucks & 4340 & 0.75 \\
4. & Tractor, Dozers, Loader & & \\
& Light & 94183 & 16.36 \\
5. & Car, jeep, van & 5300 & 0.92 \\
6. & Three wheelers & 440028 & 76.47 \\
7. & Two wheelers & 3631 & 0.63 \\
8. & CD/UN & $\mathbf{5 7 5 4 1 7}$ & $\mathbf{1 0 0}$ \\
\hline & Total &
\end{tabular}

Source: Department of Transport Management, Govt. of Nepal, 2010. 
in Kathmandu. They come for daily wage work or commercial or other purposes. It is estimated that about $20 \%$ additional population (i.e. tourists and floating population) has settled in Kathmandu Metropolis (Shrestha, 1999), with frequent cycles. This activity has also polluted the urban environment.

\section{Domestic Pollution}

Domestic pollution is mainly caused by cooking. For cooking purpose, LPG, Kerosene oil, wood dust and cow dung are used. Usually the poor and low income people who live in the congested houses use wood dust, cow dung and Kerosene oil for cooking purpose. All these produce smoke causing indoor air pollution which adversely affects their health.

\section{Air Pollution Monitoring Parameters}

The earlier study reveals that TSP and $\mathrm{PM}_{10}$ are most important pollutants in Kathmandu. The annual average concentration of TSP was found to be about $180 \mu \mathrm{g} / \mathrm{m}^{3}$ at Babarmahal measured at5m above ground level (URBAIR 1997). This is more than twice than WHO limit of 60 to 90 $\mathrm{\mu g} / \mathrm{m}^{3}$. Hence, considering the severity of the air pollutants, $\mathrm{TSp}, \mathrm{PM}_{10^{\prime}}, \mathrm{SO}_{2^{\prime}}, \mathrm{NO}_{2}, \mathrm{CO}$ and $\mathrm{Pb}$ have been monitored.

\section{Air Quality in December 1998}

The ambient air quality assessment as worked out in December 1998 and April 1999 with a time interval of 24 hours with regards to the total suspended particulate (TSP), Particulate matters less than $11 \mu$ aerodynamic $\left(\mathrm{PM}_{10}\right)$, sulfur dioxide, nitrogen dioxide $\left(\mathrm{NO}_{2}\right)$, carbon monoxide $(\mathrm{CO})$ and lead $(\mathrm{Pb})$ are shown in Table 2, December 1998.

It is evident from Table 2 that the concentration of TSP in December 1998 at Sundhara was 295 $\mu \mathrm{g} / \mathrm{m}^{3}$ whereas at kalimati it was $287 \mu \mathrm{g} / \mathrm{m}^{3}$. The TSP concentration at Chabihil was found to be $209 \mu \mathrm{g} / \mathrm{m} 3$ followed by $195 \mu \mathrm{g} / \mathrm{m}^{3}$ at Balaju and $165 \mu \mathrm{g} / \mathrm{m}^{3}$ at Thapathali. It shows that Sundhara and Kalimati stations have higher concentration of TSP than the permissible limit of WHO $\left(150-230 \mu \mathrm{g} / \mathrm{m}^{3}\right)$. Similarly the $\mathrm{PM}_{10}$ concentration was found tobe $225 \mu \mathrm{g} / \mathrm{m} 3,220$ $\mu \mathrm{g} / \mathrm{m} 3,169 \mu \mathrm{g} / \mathrm{m} 3,148 \mu \mathrm{g} / \mathrm{m} 3$ and $134 \mu \mathrm{g} / \mathrm{m}^{3}$ at Sundhara, kalimati,Chabihil, Balaju and Thapathali respectively.

The concentration of $\mathrm{SO}_{2}$, in December 1998,is $15.0 \mathrm{\mu g} / \mathrm{m} 3$ at Sundhara, Kalimati and Thapathali each. Its concentration at Kalimati and Chabihil was found to be $<20 \mu \mathrm{g} / \mathrm{m} 3$ and $14 \mathrm{\mu g} / \mathrm{m}^{3}$ respectively. Thus the $\mathrm{SO}_{2}$ concentraion is quite low as compared to the WHO limit $\left(100-150 \mu \mathrm{g} / \mathrm{m}^{3}\right)$.

The NO2 concentration at Sundhara was 13.75 $\mu \mathrm{g} / \mathrm{m}^{3}$ where as it was found to be $12.15 \mu \mathrm{g} / \mathrm{m}^{3}$, $9.65 \mu \mathrm{g} / \mathrm{m}^{3}, 8.60 \mu \mathrm{g} / \mathrm{m}^{3}$ and $8.0 \mu \mathrm{g} / \mathrm{m}^{3}$ at Kalimati, Balaju, Thapathali and Chabil respectively. Its concentration is very low than the WHO limit $\left(150 \mathrm{\mu g} / \mathrm{m}^{3}\right)$.

The highest concenttation of $\mathrm{CO}$ was found at Kalimati $\left(2.99 \mu \mathrm{g} / \mathrm{m}^{3}\right)$ followed by Thapathali

Table2: Average Concentration of Air Pollutants in Kathmandu Metropolis: December, 1998

\begin{tabular}{|c|l|l|l|l|l|}
\hline \multirow{2}{*}{$\begin{array}{l}\text { Pollutants } \\
\text { concentration } \\
\boldsymbol{\mu} \mathbf{g} / \mathbf{m})\end{array}$} & \multicolumn{5}{|c|}{ Monitoring Sites } \\
\cline { 2 - 6 } & Sundhara & Kalimati & Balaju & Chabahil & Thapathali \\
\hline $\mathrm{TSP}$ & 295 & 287 & 195 & 209 & 165 \\
$\mathrm{PM}_{10}$ & 255 & 220 & 148 & 169 & 134 \\
$\mathrm{SO}_{2}$ & 15.0 & $<20$ & 15 & 14 & 15 \\
$\mathrm{NO}_{2}$ & 13.75 & 12.15 & 9.65 & 8.00 & 8.60 \\
$\mathrm{CO}$ & 1.78 & 2.99 & 1.80 & 1.30 & 2.50 \\
$\mathrm{~Pb}$ & 0.098 & 0.069 & 0.057 & 0.020 & 0.030 \\
\hline
\end{tabular}

Source: Field Observation and Laboratory Analysis 1998. 
$\left(2.50 \mu \mathrm{g} / \mathrm{m}^{3}\right)$, Sundhara $\left(1.78 \mu \mathrm{g} / \mathrm{m}^{3}\right)$, Balaju $\left(1.80 \mu \mathrm{g} / \mathrm{m}^{3}\right)$ and Chabahil $\left(1.30 \mu \mathrm{g} / \mathrm{m}^{3}\right)$.

In the month of December 1998, the concentration of lead $(\mathrm{Pb})$ was recorded as $0.098 \mu \mathrm{g} / \mathrm{m}^{3}$ at Sundhara, $0.069 \mu \mathrm{g} / \mathrm{m}^{3}$ at Kalimati, $0.057 \mu \mathrm{g} /$ $\mathrm{m}^{3}$ at Balaju, $0.030 \mu \mathrm{g} / \mathrm{m}^{3}$ at Thapathali and $0.020 \mu \mathrm{g} / \mathrm{m}^{3}$ at Chabahil (Table 2). Thus, the concentration of $\mathrm{Pb}$ at sundhara, Kalimati and Balaju was found to be higher than the permissible limit $\left(0.05 \mu \mathrm{g} / \mathrm{m}^{3}\right)$ of WHO.

The air pollution measurement carried out in the months of april, 1999, reveals that the concentration of TSP at Sundhara was $569 \mu \mathrm{g} /$ $\mathrm{m}^{3}$ whereas at kalimati it was only $436 \mu \mathrm{g} / \mathrm{m}^{3}$. Chabhil has recorded $375 \mu \mathrm{g} / \mathrm{m}^{3}$ followed by $321 \mu \mathrm{g} / \mathrm{m}^{3}$ at Thapathali and 223 at Balaju. Thus, the TSP concentration is much higher than the WHO permissible limit (150-230 $\left.\mathrm{\mu g} / \mathrm{m}^{3}\right)$.

Table 3 reveals that the concentration of $\mathrm{PM}_{10}$ at Sundhara was $488 \mu \mathrm{g} / \mathrm{m}^{3}$. Similarly, at Kalimati , Balaju, Chabil and Thapathaliu the $\mathrm{PM}_{10}$ values were found to be $341 \mu \mathrm{g} / \mathrm{m}^{3}, 153 \mu \mathrm{g} / \mathrm{m}^{3}$ and $279 \mu \mathrm{g} / \mathrm{m} 3$ respectively which were more than double of the WHO limit $\left(70 \mu \mathrm{g} / \mathrm{m}^{3}\right)$.

The concentration of $\mathrm{SO}_{2}$ in April 1999 was found to be less than $20 \mu \mathrm{g} / \mathrm{m}^{3}$ at all the stations showing very low concentration as compared to WHO limit of $125 \mu \mathrm{g} / \mathrm{m}^{3}$. The $\mathrm{NO}_{2}$ value is less than $30 \mu \mathrm{g} / \mathrm{m} 3$ at all the sampling sites except at Sundhara where it was $30 \mu \mathrm{g} / \mathrm{m}^{3}$. The lowest concentration of $16 \mu \mathrm{g} / \mathrm{m}^{3}$ was found at
Balaju. WHO limit for $\mathrm{NO}_{2}$ is $150 \mu \mathrm{g} / \mathrm{m}^{3}$. The highest concentration of $\mathrm{CO}$ was found to be at sundhara $\left(3.42 \mu \mathrm{g} / \mathrm{m}^{3}\right)$ whereas at Chabahil, it was the lowest $\left(0.57 \mu \mathrm{g} / \mathrm{m}^{3}\right)$.

In the case of lead concentration in the ambient air, according to ministry of population and environment (MoPE) the permissible limit is 0.05 $\mu \mathrm{g} / \mathrm{m}^{3}$. The result shows that there was high concentration of $\mathrm{Pb}$ at Sundhara $\left(0.202 \mu \mathrm{g} / \mathrm{m}^{3}\right)$, Kalimati $\left(0.096 \mu \mathrm{g} / \mathrm{m}^{3}\right)$ and Chabahil $(0.058 \mu \mathrm{g} /$ $\mathrm{m}^{3}$. At Balaju and Thapathali, it was less than the permissible limit (Table 3).

The comparison between the air pollutants concentration levels measured in Kathmandu. The result shows that the TSP, $\mathrm{PM}_{10}, \mathrm{SO}_{2}$ and $\mathrm{NO}_{2}$ are found to be higher in early summer that in winter. The reason is the weather condition of Kathmandu.

To evaluate the spatial pattern of air quality in Kathmandu, concentration of $\mathrm{PM}_{10}$ has been analysed. For this purpose six monitoring stations were chosen among them, Putalisadak and Patan were selected for roadside station, Thamel for residential station, Machhegaoun for valley background station and Bhaktapur and Kirtipur for Urban background stations. $\mathrm{PM}_{10}$ is the most important air pollutant in Kathmandu Metropolis. The study reveals that the annual average concentration of $\mathrm{PM}_{10}$ at Putalisadak $204 \mathrm{\mu g} / \mathrm{m}^{3}$ (in $2004 \mathrm{AD}$ ) whereas it exceeded $228 \mathrm{\mu g} / \mathrm{m}^{3}$ (in $2006 \mathrm{AD}$ ) (Table 4). These

Table3: Average Concentration of Air Pollutants in Kathmandu Metropolis: April, 1999

\begin{tabular}{|c|l|l|l|l|l|}
\hline \multirow{2}{*}{$\begin{array}{l}\text { Pollutants } \\
\text { concentration } \\
(\boldsymbol{\mu g} / \mathrm{m} 3)\end{array}$} & \multicolumn{5}{|c|}{ Monitoring Sites } \\
\cline { 2 - 6 } & Sundhara & Kalimati & Balaju & Chabahil & Thapathali \\
\hline $\mathrm{TSP}$ & 569 & 436 & 223 & 375 & 321 \\
$\mathrm{PM}_{10}$ & 488 & 341 & 153 & 324 & 279 \\
$\mathrm{SO}_{2}$ & 18.5 & $<20$ & $<20$ & $<20$ & $<20$ \\
$\mathrm{NO}_{2}$ & 30 & 27 & 16 & 27 & 19 \\
$\mathrm{CO}$ & 3.42 & 2.00 & 0.82 & 0.57 & 1.00 \\
$\mathrm{~Pb}$ & 0.202 & 0.096 & 0.042 & 0.056 & 0.020 \\
\hline
\end{tabular}

Source: Field observation and laboratory analysis 1999. 
quantities are higher than WHO permissible level of $70 \mu \mathrm{g} / \mathrm{m}^{3}$ (Table 4 ).

Table 4 reveals that the concentration of $\mathrm{PM}_{10}$ at Patan ranges from $190 \mu \mathrm{g} / \mathrm{m}^{3}$ (2004) to $200 \mu \mathrm{g} /$ $\mathrm{m}^{3}$ (2005). The concentration of PM10 in the range of $121 \mu \mathrm{g} / \mathrm{m} 3$ to $350 \mu \mathrm{g} / \mathrm{m} 3$ lies in the category of unhealthy (CBS, 2008). Hence, the city areas of Kathmandu and Patan are not free from polluted air all over the year.

Table 4: Annual Average Concentration of PM10 $\mu \mathrm{g} / \mathrm{m} 3$ for 2004 to 2007 in Kathmandu

\begin{tabular}{|l|l|c|c|c|}
\hline \multirow{2}{*}{$\begin{array}{l}\text { Monitoring } \\
\text { Stations }\end{array}$} & \multicolumn{4}{|c|}{ Years } \\
\cline { 2 - 5 } & 2004 & 2005 & 2006 & 2007 \\
\hline Putalisadak & 204 & 199 & 228 & 227 \\
Patan & 190 & 200 & 156 & 174 \\
Thamel & 137 & 124 & 116 & 116 \\
Machagaoun & 54 & 43 & 43 & 44 \\
Bhaktapur & 112 & 99 & 91 & 76 \\
Kirtipur & 78 & 67 & 56 & 62 \\
\hline
\end{tabular}

Source: Environmental Statistics of Nepal, 2008.

\section{Consequences of Air Pollution}

A high concentration of $\mathrm{CO}$ can be lethal when $\mathrm{CO}$ is inhaled it combines with haemoglobin to form carboxyhemoglobin. Some studies reveals that even low concentration of carboxyhaemoglobin exacerbate heart attack thickening the blood vessels may affects the nervous system. $\mathrm{NO}_{2}$ is much toxic at sufficiently high concentration exposure to its fumes can irritate lung fatal effects may occour at 50 to 300 ppm and exposure to 25 ppm may result in bronchitis and bronco pneumonia. Exposure to it pulmonary tract may affect. Increase risk of viral infections higher respiratory illness rates, eye burning, chest tighten and discomfort are the other effects of $\mathrm{NO}_{2}$.

The exposure to $\mathrm{SO}_{2}$ causes irritation of eye, respiratory system, increased mucos production, cough and shortness of breath. Aggrevates heart and lung diseases, increase chronic bronchitis, asthma and cancer. It may be responsible for the decay of buildoings and monumandts.
$\mathrm{PM}_{10}$ is associated with mortality, respiratory illness including chronic bronchitis, increased asthema attack and pulmonary emphysema. Health risk due to air pollution is more in children than audult.

\section{Mitigating Measures of Air Pollution}

Air pollution can be controlled by making proper changes in raw materials, operation and system control. Dispersion of sources of air pollutants is the another method of controlling air pollution in industrial process. Contaminants should be distributed over a large area in less time and hence dilute the concentration of pollutants nears the source. Investigating the main source of inputs, contaminants should be collected which is the easiest solution of air pollution problem. The following specific measures will be appropriate to control air pollution: Unleaded petrol to reduce lead concentration in ambient air, the vehicles should be driven with electricity or hydrogen, methane as a source of energy, two stage combustion should be used to reduce the emission of $\mathrm{NO}_{2}$, evaporation should be controlled from fuel tank and carborator. Use of filter, improvement in traffic management, dust particulate emitting industries started with electrostatic precipitator, introduction of electric powered trolley bus service and strictly implementation of emission control law may be effective in controlling air pollution.

\section{Conclusion}

With the increasing standard of living and growing need of fast transportation, the number of vehicles and automobiles has been on the increase. The total number of vehicles registered in Kathmandu was 109613 by mid 1997 whereas the number reached 575417 in 2010. Such a large increase in the number of vehicles has generated and released excessive $\mathrm{CO}, \mathrm{PM}_{10}$ and dust causing air pollution. Besides these, industries and human activities have also contributed smoke and dust particles causing air pollution in the Meropolitan city. It is obvious from the study that $\mathrm{PM}_{10}$ and TSP is higher than the WHO permissible limit. 


\section{References}

CBS (2008). Environmental Statistics of Nepal. Kathmandu: Central Bureau of Statistics.

CEDA (1989). A Study on the Environmental Problems due to Urbanization in Some Elected Nagar Panchayats of Nepal. Monograph Report submitted to UNDP, Kathmandu.

Gautam, D. R. (2000) Urban Environment and Human Health in Kathmandu Metropolis. Unpublished Ph.D. Dissertation submitted to Banaras Hindu University, Varanasi.

Hardog, J.E, M. Diaena and S. Davit (1992). Environmental Problems in the Third World Cities. London: Earthscan Publication.

Perkins, H. (1974). An environmental Problems: Air Pollution. London: MC Graw Hills Ltd.

Shrestha, B. K. (1999). Prospectus of Public Private Partnerships in Solid Waste Management in Kathmandu: A Discussion. A Journal of Development. Kathmandu: National Planning Commission Secretariat 18 (2) 17-4.

Singh, J (1985). Population, Pollution and Urban Environment in H.H Singh et. al. (eds) Geography and Environment: Issues and Challenges. New Delhi: Concept Publishing Company.

Singh, S. (1995). Environmental Geography. Allahabad: Pragag Pustak Bhawan.

Tiwari, V.K. (2010). A Text Book of Environmental Studies. Mumbai: Himalayan Publishing House. 